\title{
Economic Development and Environmental Degradation in ASEAN
}

\author{
M. Irsyad Ilham
}

\begin{abstract}
The economic development in ASEAN still declines environmental quality; whereas the worst environmental quality became negative externality reduce output in many sectors of ASEAN's economy. This paper aimed to analyze the two-way relationship among economic development and environmental degradation in ASEAN with the factors that influenced it. This article used a panel data from eight ASEAN countries with the period of $2004-2013$. The analysis method used simultaneous equation model. The results showed the two-way relationship between economic development and environmental degradation in ASEAN existed. Moreover, Gross Domestic Product (GDP) per capita and energy consumption had a positive impact on environmental degradation. Meanwhile, carbon dioxide emission per capita and trade openness had a positive effect on economic development. Therefore, the economic development strategy for ASEAN countries should be directed to increase GDP per capita and reduce the energy consumption.
\end{abstract}

Keywords: economic development; environmental degradation; simultaneous equation model

\begin{abstract}
Abstrak
Pembangunan ekonomi di ASEAN masih mengabaikan kualitas lingkungan, padahal penurunan kualitas lingkungan dapat menjadi eksternalitas negatif yang dapat menurunkan output sektor-sektor ekonomi di ASEAN. Penelitian ini bertujuan menganalisis keterkaitan dua arah antara pembangunan ekonomi dan degradasi lingkungan hidup di ASEAN beserta faktor-faktor yang memengaruhinya. Penelitian ini menggunakan data panel dari delapan negara-negara di ASEAN selama periode 2004-2013. Metode analisis yang digunakan adalah model persamaan simultan. Hasil penelitian menunjukkan bahwa terdapat keterkaitan dua arah antara pembangunan ekonomi dan degradasi lingkungan hidup di ASEAN. Selain itu, PDB per kapita dan konsumsi energi berpengaruh positif dan signifikan terhadap degradasi lingkungan. Emisi karbon dioksida per kapita dan keterbukaan perdagangan berpengaruh positif dan signifikan terhadap pembangunan ekonomi. Oleh karena itu, strategi pembangunan ekonomi untuk ASEAN harus diarahkan kepada meningkatkan PDB per kapita dan mengurangi konsumsi energi
\end{abstract}

Kata Kunci: pembangunan ekonomi, degradasi Lingkungan; model persamaan simultan

\section{How to Cite:}

Ilham, M.I. (2018). Economic Development and Environmental Degradation in ASEAN. Signifikan: Jurnal Ilmu Ekonomi. Vol. 7 (1): 103 - 112. doi: http//dx.doi.org/10.15408/sjie.v7i1.6024 


\section{Introduction}

The escalation those producing goods activity still contribute as a primary factor of increasing atmospheric carbon dioxide emissions that trigger global warming (Harrington and McConnel, 2003). Underlying with several risks which could emerge from, many countries had participated in reducing the carbon dioxide emission. In this regard, ASEAN, as grouped economies cooperation, predicted to be the most significant contributor to world's carbon dioxide emissions in the future (OECD, 2012). There was still a substantial issue for this regional cooperation to develop their countries while improving environmental sustainability.

Figure 1. $\mathrm{CO}_{2}$ emission (kt) and Industry value added (million US\$) in ASEAN 2004-2013

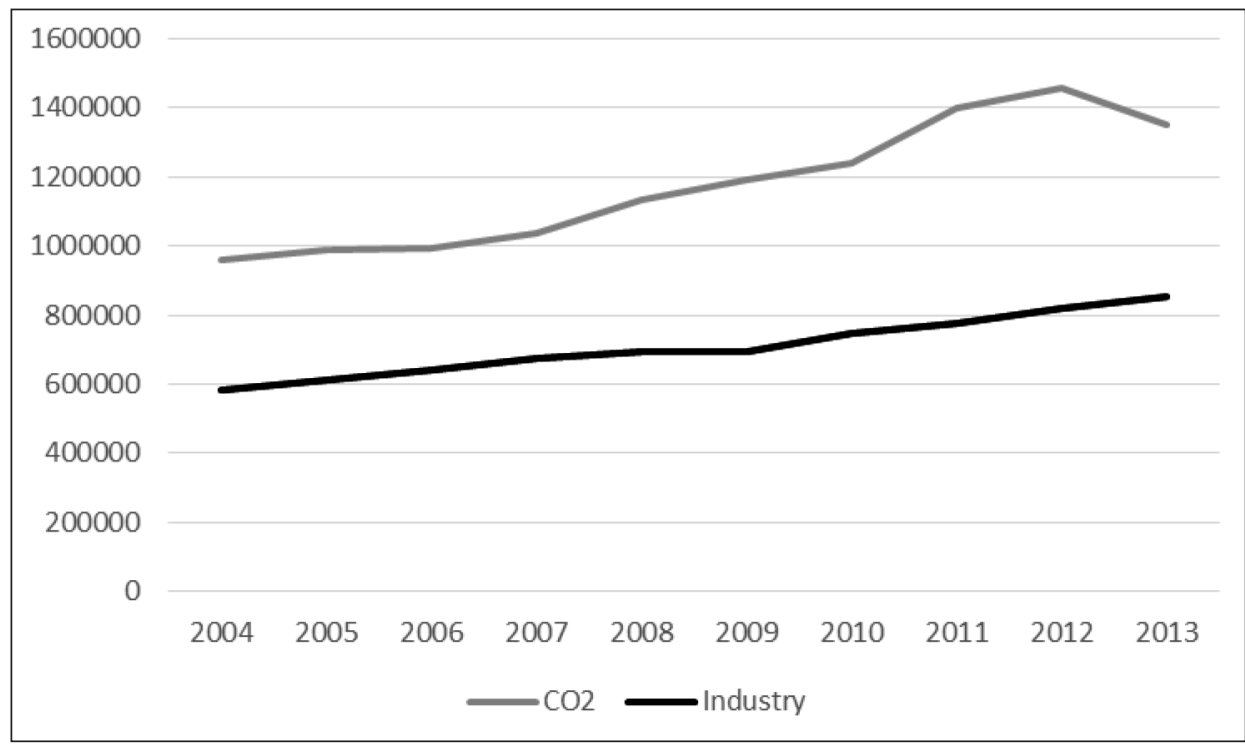

Source: World Development Indicators

Figure 1 showed that total industrial value added in ASEAN always increases over 2004-2013. On the other hand, carbon dioxide emission also tends to increase along with the increase of industrial value added. That condition showed that economic development in ASEAN less pays attention to environmental quality. Whereas, the decline of environmental quality could be negative externalities, which affected to decrease production in many sectors of economies. The economic development that was too focused on the pursuit of economic growth often ignores the environmental sustainability. Therefore, the development of the economies challenges by environmental degradation problems (Ogborn and Anga, 2015).

Several studies showed the relationship between economic development and environmental degradation. Stern (2004) said that through a curve named Environmental Kuznets Curve (EKC), environmental degradation and pollution would increase in the early stages of economic development, but beyond some levels, economic growth will lead to environmental improvement. Thus, Arouri et al (2012) stated that real GDP had a significant impact on long-term toward carbon dioxide emission. Their research also showed that real GDP and carbon dioxide emissions had a quadratic relationship. 
Moreover, Farhani et al (2014) who investigating the dynamic relationship between carbon dioxide emissions, output, and trade, found that energy consumption, trade, GDP, and quadratic GDP caused CO2 emissions.

Also, Stern et al (1996) had stated that among environmental degradation and economic development had a two-way relationship. Moreover, Hung and Shaw (2006) found that simultaneity between environmental quality and economic development existed. Based on Kuznet hypothesis through Environmental Kuznets Curve (EKC), it showed that GDP per capita could affect environmental degradation. On the other hand, environmental quality also could impact positively on GDP per capita.

Hence, there was simultaneity relationship among environmental degradation and economic development. Besides the two way relationship among environmental degradation and economic development, there were also other variables that had a relationship not only on GDP per capita but also Carbon dioxide emission per capita. Carbon dioxide emission per capita would affect energy consumption per capita (Arouri et al, 2012; Farhani et al, 2014; Omri, 2015). Also, GDP per capita would be affected by foreign direct investment (Mahmood and Chaudhary, 2012; Abdouli and Hammami, 2016), and trade openness (Farhani et al 2014).

Hence, the novelties of this paper were the implementation of simultaneous equation model with panel data. Thus, this application has implemented the data in ASEAN countries since there will the biggest contributor of $\mathrm{CO} 2$ in this regional, as well as predicted by OECD. Using simultaneous equation model with panel data will make estimation unbiased so that it will more accurate to explain causal relationship according to the environmental degradation problems. Then, to keep the sustainability of environmental quality in the world, United Nations (UN) formulated Sustainable Development Goals (SDGs), which had 17 main goals. On the other side, ASEAN Economic Community (AEC) is a form of international cooperation to implement sustainable development in the world. Therefore, the economic policies in ASEAN should consider the environment as one of the objects of development so that the economic integration does not lead to the environmental degradation in ASEAN. Implementation of new method will make the estimation more accurately in line with the motivation to formulate policies in reducing carbon dioxide emissions.

Hence, this paper aimed to analyze the two-way relationship between economic development and environmental degradation in ASEAN. Besides that this article also wants to examine the factors that influenced economic development and environmental degradation in ASEAN. Several environmental-based economic development strategies for AEC also mentioned in conclusion based on the empirical result.

\section{Method}

This paper used a panel data from eight countries in ASEAN and period $2004-2013$ annually. The data collected from World Development Indicator. The indicators included carbon dioxide emissions (metric tons per capita), GDP per capita (constant 2010 US\$), 
energy use (kg of oil equivalent per capita), foreign direct investment (balance of payment (BoP, current US\$), and trade openness (\% trade of GDP). The eight ASEAN countries for this panel analysis were Brunei Darussalam, Cambodia, Indonesia, Malaysia, Philippines, Singapore, Thailand, and Vietnam. Lao PDR and Myanmar excluded from the study because of the unavailability of the data.

The purpose of this paper was to analyze the two-way relationship among economic development and environmental degradation in ASEAN with the factors, which influenced it. The proxy of environmental degradation was carbon dioxide emissions per capita. Stern et al (1996) state that among environmental degradation and economic development had a two-way relationship. As Stern (1998) concluded estimating single equation relationships by ordinary least square where simultaneity exists produces biased and inconsistent estimates. Borghesi (1999) also stated that a simultaneous-equation model might be more appropriate for understanding the environment-income relationship.

In this paper, there would be the two-way relationship or dual causality between environmental degradation and economic development. This research applied simultaneous Equation Model with Panel Data to analyze environmental degradation in ASEAN. The specification of the model, consist of two structural equations, could seem as follows:

$$
\begin{aligned}
& \ln \left(\mathrm{CO}_{2 \mathrm{it}}\right)=\beta_{01}+\beta_{11 \mathrm{i}} \ln \left(\mathrm{GDPC}_{\mathrm{it}}\right)+\beta_{21 \mathrm{i}} \ln \left(\mathrm{ENC}_{\mathrm{it}}\right) \\
& \ln \left(\mathrm{GDPC}_{\mathrm{it}}\right)=\beta_{02}+\beta_{12 \mathrm{i}} \ln \left(\mathrm{CO}_{\mathrm{it}}\right)+\beta_{22 \mathrm{i}} \ln \left(\mathrm{FDI}_{\mathrm{it}}\right)+\beta_{32 \mathrm{i}} \ln \left(\mathrm{TOP}_{\mathrm{it}}\right)
\end{aligned}
$$

Where:

$\mathrm{CO} 2=$ carbon dioxide emissions per capita (in metric tons)

$\mathrm{GDPC}=$ real GDP per capita (in US\$)

$\mathrm{ENC}=$ energy consumption per capita (in $\mathrm{kg}$ )

FDI = foreign Direct Investment (current US\$)

$\mathrm{TOP}=$ trade openness (in percentage of GDP)

In this paper, those two structural forms write in natural logarithmic form. This condition due to make easy in the interpretation of the estimation result. By using natural logarithmic from the two-sided equation, from those two equations, the interpretation of those model would use the percentage term. It should remind, this paper used panel data form. Panel data used due to its benefit besides using others data form. The procedure of simultaneous equation model showed as followed: First, model specification; second, model identification; Third, parameter estimation; Fourth, parameter testing; Fifth, model evaluation; and sixth, interpretation.

\section{Result and Discussion}

During 2004-2013, carbon dioxide emission in ASEAN tends to increase by commonly 5.23 percent each year. Carbon dioxide emission in ASEAN during that period had approximately 1.2 billion ton each year with the standard deviation 0.18 billion ton. Indonesia was the most prominent contributor to carbon dioxide emission since 2004 until 
2013. Indonesia's share of carbon dioxide emission in ASEAN region was 35.54 percent in 2013, followed by Thailand (22.47\%), Malaysia (17.53\%), and Vietnam (11.31\%). It was not a pleasant condition that in 2010, the result of Bradshaw et al (2010) that Indonesia includes as the most prominent contributor of environmental degradation in the world below Brazil, United States, and China.

Figure 2 showed carbon dioxide emission per capita. From eight ASEAN countries which include in the analysis, almost all of them had the same pattern of carbon dioxide emissions per capita trends except Singapore and Brunei Darussalam. More profoundly, between Singapore and Brunei Darussalam had the same trend decreasing carbon dioxide emission per capita during 2004-2006. The same thing also happened for the two countries when 2012-2013. Based on EKC, this condition would occur because of the increase of wealth in that country. If economies reach high income so the environmental degradation cases should be decline. Of course, while another ASEAN countries showed the increase in their carbon dioxide emission per capita but another side of wealthy countries in this region had the distinguish from except Singapore and Brunei Darussalam.

Figure 2. Carbon dioxide emission per capita in eight countries ASEAN 2004-2013

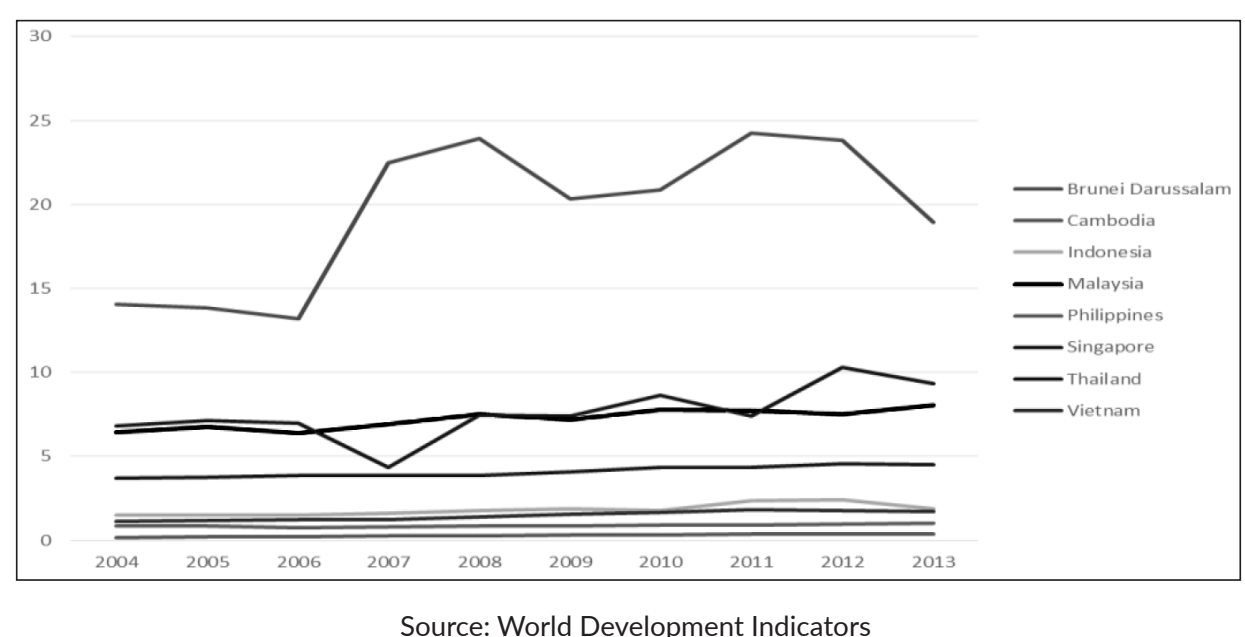

Real GDP of ASEAN had increased over time during 2004 until 2013. During this ten years, it could show that total output from all economic activity in ASEAN was an increase. The increase in the production of economic activity was one of the indications the achievement of the economic development process in ASEAN on accelerating its regional economic growth. To stimulate economic growth, there was tendency that the residual from the activity increase. The increasing of carbon dioxide emission effects the declining of air quality in this region (Figure 3). Finally, accumulation of the emission would make environmental degradation that it would be affected in many aspects of human lives in many ASEAN countries. 
Figure 3. $\mathrm{CO}_{2}$ emission (kt) and GDP (million US\$) in ASEAN 2004-2013

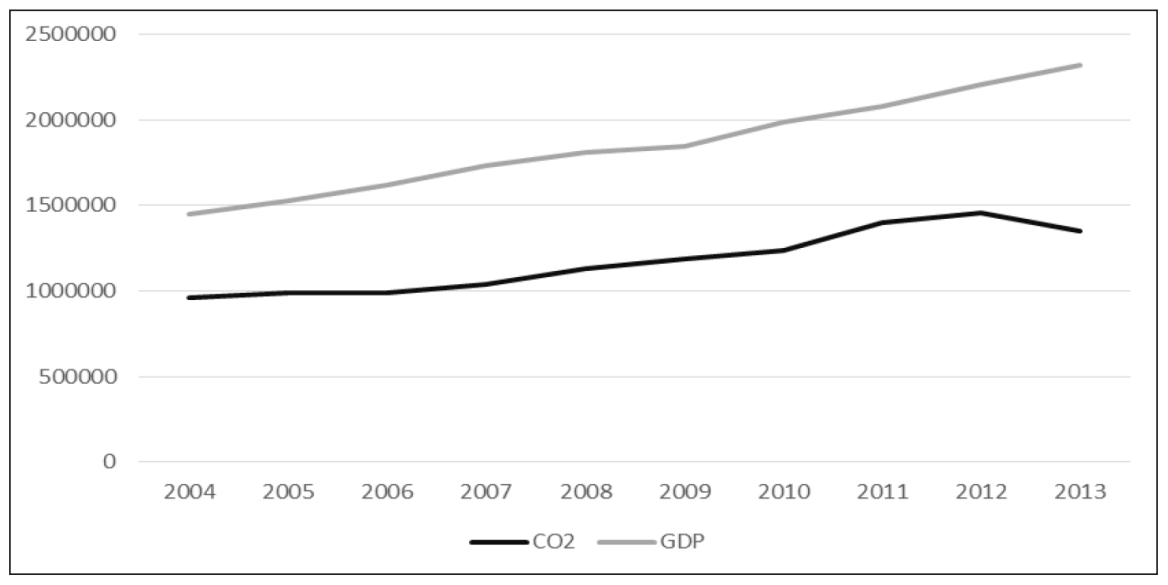

Source: World Development Indicators

Environmental degradation in ASEAN seems had a relationship with economic development. During 2004-2013, the increase of carbon dioxide emission always followed by the rise in industrial value added. Then, when carbon dioxide decreases in 2012-2013, industrial value-added also decreased. Moreover, industrial value added and carbon dioxide emission had positive relationship each other. Hence, the simultaneous equation model with panel analysis performed on the two-way relationship among economic development and environmental degradation in ASEAN with the factors, which influenced it.

Table 1. Estimation Result EC2SLS Estimator (For Equation 1)

\begin{tabular}{ccccc}
\hline Endogenous variable & Exogenous Variable & Coefficient & p-value & Statistical Summary \\
\hline LnCO2 & Intercept & -8.220 & 0.000 & R-Square $=0.8852$ \\
& LnGDPC & 0.615 & 0.000 & \\
& LnENC & 0.550 & 0.000 & \\
\hline
\end{tabular}

Source: STATA output

The relationship between environmental degradation and economic development analyzed with EC2SLS and FE2SLS estimator, as seem as Table 1 and Table 2. Based on the equation (3) and (4), it appears that there was a significant two-way relationship between environmental degradation and economic development. From its p-value that smaller than significance level at five percent, GDP per capita had a significant effect on carbon dioxide emission per capita. Also, by five percent significance level, carbon dioxide emission per capita also has a significant impact on GDP per capita. The change of GDP per capita by one percent, so carbon dioxide emission per capita would lead to increase by 0,615 percent, with the assumption that other variables are constant. If the carbon dioxide emission per capita increase one percent, GDP per capita would increase 0,401 percent, with condition ceteris paribus. 
Table 2. Estimation Result FE2SLS Estimator (For Equation 2)

\begin{tabular}{ccccc}
\hline Endogenous variable & Exogenous Variable & Coefficient & p-value & Statistical Summary \\
\hline LnGDPC & Intercept & -8.498 & 0 & R-Square $=0,7303$ \\
LnCO2 & 0.401 & 0 & \\
LnFDI & 0.029 & 0.056 & \\
LnTOP & -0.212 & 0.015 & \\
\hline
\end{tabular}

Source: STATA output

The result of the estimation from Table 1 and Table 2 of structural model was as follows:

$$
\begin{aligned}
& \operatorname{lnCO}_{\text {it }}=-8.220+0.615 \operatorname{lnGDPC}_{i t}+0.550 \operatorname{lnENC} C_{i t} \\
& (\mathrm{p} \text {-value })(0.000) \quad(0.000) \quad(0.000) \\
& \operatorname{lnGDPC}_{\text {it }}=8.498+0.401 \operatorname{lnCO} 2_{i t}+0.029 \mathrm{FDI}_{\mathrm{it}}-0.212 \operatorname{lnTOP} \mathrm{P}_{\mathrm{it}} \\
& (\mathrm{p} \text {-value })(0.000) \quad(0.000) \quad(0.056) \quad(0.015)
\end{aligned}
$$

This result had the similar case with Hung and Shaw (2006), which said that there was the two-way relationship among economic development and environmental degradation in Taiwan. The increase of income per capita would lead environmental quality decline. Both researchers argued the rise in pollution (such as PM10, NO2, and CO) in line with the escalation of income per capita. The previous study from Paudel and Pandit (2003) had the similar result with the slope sign in this research. The research showed that income per capita positively impacts on environmental degradation. Their study used phosphorus quantity, Biochemical Oxygen Demand (BOD), and mercury as proxy environmental degradation.

The result of this research consistent with Kuznets' hypothesis about environmental degradation. According to Environmental Kuznets Curve (EKC) hypothesis, the economic progress could give positive and negative impact on the environment. In the earlier stage of development of a nation may cause several environmental damages so the environmental quality becomes low. This situation happened due to industrialization that produces residual so that economic development may negatively impact the environment condition. Thus, at the wealth stage of a nation, economic activity tends to impact on environmental quality positively. Since the wealthy nation's economic threshold dominated by a service sector that produces small quantity of residual, the positive impact from economic development on environmental quality also caused by the development of eco-friendly technology.

Despite GDP per capita had significant effected on per capita CO2 emissions, the estimates of Cobb-Douglas equation in Equation 4 showed that the effect of CO2 per capita emissions on income is also vital. The multiple roles of air pollution on production tent to counteract each other. On the other hand, pollution was an externality causing an adverse effect on output per se and the productivities of different input. Thus, environmental variables affect production via environmental policies that raise the production cost and reduce outputs. Improving the environmental quality, therefore, makes production decreased (Hung and Shaw, 2006). Then, it should consider about environmental policies in ASEAN might be a significant necessity so that the government in each country in ASEAN budgeting 
several costs to improve environmental quality such as raising production cost. Admittedly, if producers include environmental cost, it will lead to excavate production cost and make reducing production.

Returning to the equation (3) showed that the factor except for GDP per capita that affected carbon dioxide emission significantly was energy consumption per capita. The energy consumption per capita had a positive impact on carbon dioxide emission per capita in ASEAN. In the ceteris paribus condition, the increase of energy consumption per capita by one percent would lead to increase carbon dioxide emission per capita by 0.55 percent. This result was similar to the study from Arouri et al (2012). Their study about the impact of economic growth and energy consumption in carbon dioxide emissions in MENA countries showed that there was a positive relationship between CO2 emissions per capita and energy consumption. Besides, the study of Rahman (2017) also found a positive and significant impact of energy consumption per capita on $\mathrm{CO} 2$ emissions for all countries in the sample except for Indonesia.

Besides environmental degradation, the factors influenced significantly on GDP per capita were trade openness. The trade openness had an adverse GDP per capita. When other variables are constant, one percent increase in trade openness will lead to decrease GDP per capita by 0.212 percent. The impact of trade openness on economic growth is a subject of debate in the existing literature. The effect was found to be positive in some studies and non-significant or even negative in others. The mixed results might attribute to the analytical framework and country-specific characteristics. Several studies argued the negative impact trade openness on economic development because the countries which specialize in the production of low-quality products (Keho, 2017). Also, the result indicates that greater trade openness exerts an adverse effect on economic growth for ASEAN regions. Meanwhile, Kim et al (2012) provide evidence that trade openness has a negative impact on low-income, highinflation, and agricultural countries. As known, many countries in ASEAN was agricultural countries. Many less developed economies may not be able to realize the potential gains from trading with more technologically advanced economies. Only when reaching a threshold level of development, will the economies be able to make effective use of technological spillovers.

In equation (4), some variables affected GDP per capita in ASEAN. If more deeply see, there were foreign direct investment variable. Foreign direct investment had no significant effect on GDP per capita in ASEAN. The foreign direct investment was the investment term that needed by all countries to improve their economic activity. From the coefficient in equation (4), foreign direct investment had a positive impact on GDP per capita in ASEAN.

Moreover, the result of Haussmann specification test for those two equations each of them, produce the value 5.7 and 258.17. Hence, for the first equation, by using 95 percent confidence interval, not sufficiently proven to state that there was a systematic distinction between FE2SLS and EC2SLS. With another word, EC2SLS estimator, which used to estimate the parameters in the first equation for this simultaneous equation model was efficient and consistent. But, for the second equation, by using 95 percent of the confidence interval, there was sufficiently proven to state that there was systematic distinction between FE2SLS and EC2SLS. With another word, the EC2SLS estimator would be inefficient and 
inconsistent with the estimate the parameters. The second equation used FE2SLS estimator to estimate the determinant of GDP per capita in ASEAN 2004-2013.

Equation (3) had R-square 88.52 percent. It means the explanatory variable in the first equation structural form could explain the variation in the value of carbon dioxide emission per capita by 88.52 percent. Besides, 11.48 percent the variation explained by other variables outside this first structural equation form. Equation (4) had R-square 73.03 percent. It means the explanatory variable in the second equation structural form could explain the variation from the value of GDP per capita by 73.03 percent. Besides, 26.97 percent the variation explained by other variables outside this second structural equation form. The ability of simultaneous equation model used to analyze the two-way relationship between environmental degradation and economic development in ASEAN during 2004-2013 in this paper could say that appropriate.

\section{Conclusion}

The environmental quality in ASEAN countries tends to decrease over time. By using simultaneous equation model with panel data, the two way relationship among economic development and environmental degradation in ASEAN was exist. GDP per capita and energy consumption per capita had positive impact on environmental degradation. On the other hand, the carbon dioxide emission per capita had a positive effect on economic development; meanwhile, trade openness had an adverse impact on economic development in ASEAN.

Therefore, the economic development strategy for ASEAN countries should direct to the increase of GDP per capita and the reduction of energy consumption. Some environmental-based economic development strategies or policies that could implement as AEC are: first, export-oriented trade policies to increase GDP per capita; second, energy source transformation, from fossil fuels to renewable energy resources, to decrease the energy consumption which caused environmental degradation.

\section{Acknowledgments}

Thanks to the staff in Central Statistics Agency for the support in the submission of this paper. Also, for the editors for their comments on the initial draft of this paper. Also, I wish thank a committee of International Conference of Indonesian Economic Development (ICIED) for the chance to publish this article in Journal.

\section{References}

Abdouli, M., \& Hammami, S. (2016). Investigating the Causality Links Between Environmental Quality, Foreign Direct Investment and Economic Growth in MENA Countries. International Business Review. Vol. 26 (2): 264-278. doi: 10.1016/j.ibusrev.2016.07.004

Arouri, M.E.H., Youssef, A.B., M'henni, H., \& Rault, C. (2012) Energy Consumption, Economic Growth and $\mathrm{CO}_{2}$ Emissions in Middle East and North African Countries. Energy Policy. Vol. 45: 342-349. doi: 10.1016/j.enpol.2012.02.042. 
Borghesi, S. (1999). Natural Capital and The Economics of Environment and Development, in Jansson, A., M. Hammer, C. Folke and R.Constanza, (eds). Investing in Natural Capital: The Ecological Economics Approach to Sustainability. New York: Columbia University Press.

Bradshaw, CJ.A., Giam, X., \& Sodhi, N.S. (2010). Evaluating the Relative Environmental Impact of Countries. PLos One, 5(5), e (10440). doi: 10.1371/journal.pone.0010440.

Farhani, S., Chaibi, A., \& Rault, C. (2014). A Study of CO2 Emissions, Output, Energy Consumption, and Trade. IPAG Business School Working Paper Series 2014-056.

Harrington, W. \& McConnel, V. (2003). RFF Report-Motor Vehicles and The Environment. Washington DC: Resource for the Future

Hung, M.F., \& Shaw, D. (2006). Economic Growth and the Environmental Kuznets Curve in Taiwan: A Simultaneity Model Analysis. In Boldrin, M., (eds). Long-Run Growth and Economic Development: From Theory to Empirics. United Kingdom: Edward Elgar.

Keho, Y. (2017). The Impact of TradeOpenness on Economic Growth: The Case ofCoted'Ivoire. Cogent economics and Finance. Vol. 5: 1-14. doi: 10.1080/23322039.2017.1332820.

Kim, D-H, Lin,S-C, and Suen, Y.B. (2012). The Simultaneous evolution of economic growth, financial development, and trade openness. The Journal of International Trade and Economic Development. Vol. 21: 513-537. doi: 10.1080/09638199.2010.497933.

Mahmood, H., \& Chaudhary, A.R. (2012). FDI, Population Density, and Carbon dioxide Emissions: A Case Study of Pakistan. Iranica Journal of Energy \& Environment. 3 (4): 354-360.

OECD. (2012). Southeast Asian Economic Outlook 2011/12. Paris: OECD Publishing. doi: 10.1787/9789264166882-en.

Ogborn, I., \& Anga, R.A. (2015). Environmental degradation and Sustainable Economic Development in Nigeria: A Theoretical Approal. Research Journal of Economics. Vol.3 (6): 551-564.

Omri, A. (2015). Co2 Emissions, Energy Consumption and Economic Growth Nexus in MENA Countries: Evidence from Simultaneous Equations Model. Available at SSRN: $\mathrm{http}: / /$ ssrn. com/abstract $=2643733$

Paudel, K.P., \& Pandit, M. (2013). Environmental Kuznets Curve in Stock and Flow Water Pollutans: A Seemingly Unrelated Partially Linear Analysis. Conference Paper at Agricultural and Applied Economics Association. Washington DC.

Rahman, M.M. (2017). Do Population Density, Economic Growth, Energy Use and Export Adversely Affect Environmental Quality in Asian Populous Countries? Renewable and Sustainable Energy Reviews. Vol. 77: 506-514. doi: 10.1016/j.rser.2017.04.041.

Stern, D.I., Common, M.S., \& Barbier, E.B. (1996). Economic Growth and Environmental degradation: The Environmental Kuznets Curve and Sustainable Development. World Development. Vol. 24 (7): 1151-1160. doi: 10.1016/0305-750X(96)00032-0.

Stern, D.I. (1998). Progress of the Environmental Kuznets Curve? Environment and Development Economics. Vol. 3 (2): 173-196.

Stern, D.I. (2004). The Rise and Fall of the Environmental Kuznets Curve. World Development. Vol. 32 (8): 1419-1439. doi: 10.1016/j.worlddev.2004.03.004. 